\title{
The Effect of Human Resource Competency, Work Culture and Utilization of Information Technology to Performance of Employees
}

\author{
Kasih Mey Hana Indiyaningsih \\ Departement of Labor, Lumajang Regency \\ meyhana10964@gmail.com
}

\begin{abstract}
The development of technology nowadays is so rapid along with the development of technology-based information systems, this is what causes rapid changes in various fields. Information technology in this case is one pillar of success in the era of globalization, policy making in companies is demanded to be as efficient as possible to continue to maintain the survival of the organization. Analysis of data using linear regression. Data collection techniques using questionnaires, interviews, non-participant observation. The population of this study is the Aparatur Sipil Negara in the Badan Kepegawaian Daerah Kabupaten Lumajang. In sampling using a saturated / census sampling technique. Because the number of ASN is less than 100 people, namely 49 people. Thus the entire population is sampled in this study.
\end{abstract}

Keywords : Employee Performance, Information Technology Utilization

\section{INTRODUCTION}

In line with the development of science and technology, especially in the field of government today there have been enormous changes, one of which is in the implementation of regional autonomy. One of the changes is realizing democratic and good governance (democratic and good governance). One element of the administration of government that needs attention in the reform effort is the structuring of the government apparatus which includes the institutional arrangement of the government bureaucracy, the system, and the management of human resources management in this case the Aparatur Sipil Negara (ASN). Therefore, it is needed a government apparatus that has the quality and professionalism in carrying out and completing a job. Personnel structuring continues and continues to undergo administrative staff improvements to support high employee performance, which in turn will also make the performance of the organization / agency good.

With the information technology-based information system in Lumajang Regency, the change in technology and information requires all components to keep abreast of changes that continue to occur. Changes that occur become a challenge that needs to get serious attention from the managers of regional charitable organizations in managing their organizations. The still low quality of human resources and its handling is one of the problems being faced by the Lumajang Regency government. The large amount of human resources if it can be used effectively and efficiently will be very beneficial to support the country's national development. 
Where the number of ASNs in Lumajang Regency was 7390 ASNs, spread over 43 agencies / offices, 21 subdistricts, 25 puskesmas, 3 UPT health offices, 21 coordinators. Educational Services. All ASN has implemented all SIMAK because all staffing data must be accessed at SIMAK starting from pre-service until retirement. To be able to access SIMAK it is necessary to enter a username and password which by entering the Employee Identification Number (NIP) can only be accessed which contains personnel administration starting from personal data, types of hours worked, employment history, level of education, periodic, rank, leave, awards , training and others. SIMAK accessed through the website there are also Employee Performance Targets (SKP) and SIPERLU recapitulation about the attendance and absence of employees. In the SKP we access work plans, targets to work achievements, must be online here and then to be asked for approval from superiors then BKD. While SIPERLU in SIMAK, we can see and control the level of employee attendance. Whereas for the use of SIPERLU, there were only $91.3 \%$ of the total ASN, the rest were some obstacles in using SIPERLU, namely the location that was not reached by the signal, did not have an android mobile phone (data source: BKD Lumajang Regency).

SIPERLU is part of the SIMAK application that is specialized in handling the administration of the ASN presence in the Lumajang Regency Government. With the existence of SIPERLU, the ASN presence will be recorded online and systematically using the android devices that are owned by each ASN as the medium (mobile). SIPERLU works according to the time and location of work or the coordinates of the agency where the ASN works.

At present with the existence of SIPERLU in which there are descriptions of daily activities that must be explained in the application system in addition to being a support. As Regent Regulation No. 38 of 2019 regarding Additional Income Improvement (TPP) is also one of the benchmarks of employee performance in Lumajang Regency. Because in it there is an assessment of employee performance by $20 \%$ which is the responsibility of ASN. Employee performance activities carried out by ASN are very important, TPP is not given free of charge. TPP is given based on presence and must also be related to ASN performance. To support this, BKD Lumajang Regency issued the SIPERLU android application. Giving TPP using SIPERLU has a weight of $60 \%$ of the receipt of TPN ASN. While other factors that can support the size of TPP processors are work activities recorded using SIPERLU weighing 20\%, implementation of SAKIP OPD 10\% and budget absorption of 10\%. Starting from the background of the problem, the authors formulate the problem as follows. Does the use of information technology affect the performance of employees in Badan Kepegawaian Daerah Lumajang Regency?

\section{METHODOLOGY}

This study uses a quantitative approach. The research location is in Lumajang Regency with a population of 49 people and the sampling technique uses saturated / census sampling techniques so that the overall population is sampled. Data collection 
techniques using questionnaires, observations and documentation to strengthen the background and non-participant observation. The collected data is then analyzed using linear regression.

\section{A. Definition of Variable Operations}

1. Employee Performance (y)

This study defines performance as the leadership's perceptions regarding the results obtained by employees both qualitatively and quantitatively, in accordance with the authority of duties and responsibilities. Employee performance in Mangkunegara (2009) [3] is measured by indicators such as the following:
a. Quality of Work
b. Work Quantity
c. Responsibility
d. Cooperation
e. Public Service

2. Utilization of Information Technology $(x)$

Utilization of information technology is the benefits expected by information users in carrying out tasks through: the use of hardware, the use of software and the use of brain ware to support staffing administration and others in the context of carrying out work responsibilities. Technology utilization indicators were developed based on research by Nuryanto, M. and N. Afiah (2013):
a. Hardware Utilization
b. Software Utilization
c. Brainware Utilization

\section{B. Classic Assumption Test}

Prior to the multiple linear regression analysis, the following classic assumptions are made:

\section{Normality Test}

This figure below shows that data in paths 1 and 2 spread around the diagonal and follow the direction of the diagonal line, so the regression model meets the normality assumption. 


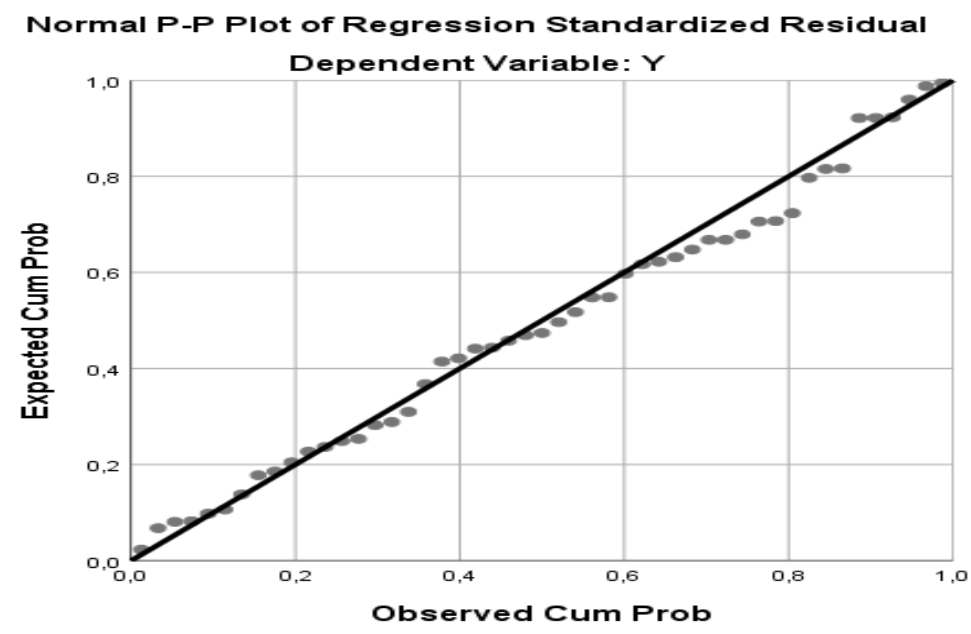

Figure 1. Model Normality Test Result

2. MulticollinearityTest

The results of the multicollinearity test showed that both model- 1 and model-2 had a VIF of less than 5, coefficients tolerance approached 1 and $\mathrm{CI}<30$, so that there was no multicollinearity.

Table 1. Multicollinearity Test Result

\begin{tabular}{lllll}
\hline Variabel & VIF & $\begin{array}{l}\text { Coeff. } \\
\text { Tolerance }\end{array}$ & CI & Information \\
\hline $\mathrm{X}$ & 1,188 &, 842 & 23,394 & $\begin{array}{l}\text { Multicollinearity } \\
\text { does not accur }\end{array}$ \\
\hline
\end{tabular}

3. Heteroskedacity Test

In figure below can be seen the data distribution does not form a specific or random line. This means that the independent variables do not form heteroscedasticity.

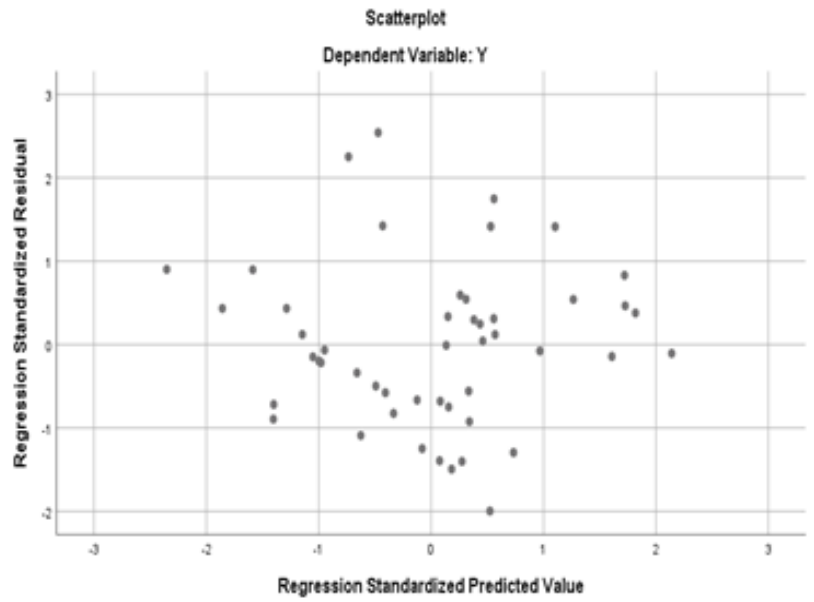

Figure 2. Heteroscedasticity Test Result

C. Multiple Linear Regression Analysis

The following are the results of the multiple linear regression analysis. 
Table 2. Result of multiple linear regression analysis

\begin{tabular}{|c|c|c|c|c|c|c|}
\hline \multicolumn{7}{|c|}{ Coefficients $^{\mathrm{a}}$} \\
\hline \multirow{2}{*}{ Model } & $\begin{array}{c}\text { Unstandardized } \\
\text { Coefficients }\end{array}$ & $\begin{array}{c}\text { Standardized } \\
\text { Coefficients }\end{array}$ & $t$ & Sig. \\
\cline { 3 - 7 } & B & $\begin{array}{c}\text { Std. } \\
\text { Error }\end{array}$ & Beta & & \\
\hline \multirow{2}{*}{1} & (Constant) & $-29,000$ & 13,696 & & $-2,117$ &, 040 \\
\cline { 2 - 8 } & X &, 814 &, 251 &, 378 & 3,247 &, 002 \\
\hline
\end{tabular}

Based on the table, the linear regression equation can be arranged as follows: $y=$ $29,000+0,814 \times$

\section{T Test}

Effect of utilization of information technology (x) on employee performance (y). Obtained data obtained for the variable human resource utilization of 3.247 which is greater than ttable $(3.247>1,677)$ with a probability level of $0.002<0.05$ so it can be interpreted that the variable information technology utilization $(\mathrm{x} 3)$ partially has a significant effect on the variable performance $(y)$.

\section{F Test}

Obtained that Fcount $=14,291$. At a significance of 5\%, a Ftable of 2.810 was obtained, which means Fcount> Ftable (14.291> 2.810) so that the variables $\mathrm{x}$ had a significant simultaneous effect on the variable $y$.

\section{Coefficient of Determination (R2)}

The coefficient of determination (R2) of 0.488 which means that employee performance is influenced by human resource competence, work culture and information technology utilization by $48.8 \%$ and the remaining $51.2 \%$ is influenced by other factors not included in this study.

\section{RESULTS AND DISCUSSION}

A. Effect of Utilization of Information Technology on Employee Performance

This shows that employee performance is influenced by the use of information technology. The results of the analysis and hypothesis testing state that the use of information technology is proven to have a direct and significant influence on employee performance. When technology has become a necessity, then the availability of information technology is one of the determinants of performance improvement. The suitability of the task with the technology used will affect the speed and accuracy of employees in completing work. The existence of technology-based tasks will support employees to encourage employees to be able to utilize the technology provided to facilitate work. If BKD is able to utilize information technology effectively, it will be able to produce information that can be received in a timely, accurate and reliable manner which in turn will improve employee performance. Improved employee performance, can improve overall organizational performance. The use of information 
technology to improve employee performance is measured by the use of hardware, the use of software, the use of brainware. Employees who have high utilization of information technology have the following characteristics using a computer with a high processor speed, using a computer with a large capacity hard drive to store data, using the internet network as a media of information in support of work, understanding the functions and workings of applications, understanding of what to do if there are problems with the application.

The results of this study are consistent with the theory put forward by Robbins (2003: 149), employee performance is influenced by the condition of the use of information technology around organizational employees. In addition these results support the opinion of Jaryono in Triyandari's research (2016), information technology has played a strategic and significant role in organizations. Improved hardware and software support has led to the tendency of a decentralized system that allows divisions within an organization to have their own computers.

Employee performance is a reflection of employee feelings towards their work. This finding supports theories of employee performance and also previous research.

The biggest contribution in influencing employee performance is This certainly supports the opinion of Hendrico, M. (2014). Synergy results from a number of factors, both internal factors, which the higher the internal factors, the higher the employee's performance. Conversely, the lower these factors, the lower the performance. The second is the internal factors of the organization, where in carrying out their duties, employees need the support of the organization where they work. This support affects the level of employee performance. Therefore, organizational management must create a conducive internal environment of the organization so as to support and improve employee performance. The third factor is the external environment of the organization, where circumstances in the organizational environment or outside the organization affect performance.

\section{CONCLUSION}

Employees who have good work attitude, knowledge and skills, tend to have good performance too. This illustrates that employees can work with high self-confidence and sincerity in completing the given task.

Such conditions prove consistent behavior and high commitment and describe a conducive way of working in the work environment. It also shows the willingness of employees to share correct information with other employees, meaning that employees can work with actual and accountable information to obtain maximum results and benefit the organization.

There is still a doctrine in yourself about old values or habits because the length of work makes the mindset rather difficult to change. Likewise with the existence of information technology, both directly and indirectly, plays a strategic and significant role in the organization, in terms of hardware utilization, software utilization, and brainware utilization. Employees who are willing and able to adapt to new things 
based on good competence, in the face of changes in information technology, will not experience difficulties in their use.

\section{SUGGESTION}

Based on the description of the discussion and conclusions above, researchers can express some suggestions, among others, as follows:

1. The leader must place the employee in the field of work in accordance with his educational background / competence, so that the employee can work optimally.

2. Employee competency to be continuously improved, bearing in mind the increasingly high performance demands and quality because competition in the work world is getting tougher. In the future, bureaucratic organizations are demanded to be more competent professionals in their fields.

3. For other researchers, it is expected to be able to develop this research in a broader scope, because there are still many things that can be revealed or developed with other variables that are more innovative, so that it will add discourse for developers of administrative science.

\section{REFERENCES}

Haryanto. Regional Financial Management and Accounting. Semarang: UNDIP Press Semarang.2013.

Hendrico, M. Factors Influencing Employee Performance in the Culture and Tourism Office of Pekanbaru City. Jom Fisip Riau University. Vol. 1 No.2. 2014

Mangkunegara, P. A. Human Resources Management [in Indonesian]. Bandung: Youth Rosda Karya. 2009.

Nuryanto, M., and N. Afiah. The Impact of Apparatus Competence, Information Technology Utilization and Internal Control on Financial Statement Quality (Study on Local Government of Jakarta Province - Indonesia)[in Indoensian]. World Review of Business Research Vol.3.No. 4 Issue.Pp. 157 - 171. 2013.

Robbins, Stephen.P. Organizational Behavior [in Indonesian]. Jakarta: Index.2003.

Triyandari, N. Influence of the Use of Information Technology on Employee Performance (Case Study of STMIK Duta Bangsa Employees) [in Indonesian] .ISSN: Volume 11 Number 1, 2086: 2086 - 9436. 2016. 